\title{
Nederlands Epilepsie Netwerk
}

Het Nederlands Epilepsie Netwerk is een nieuw initiatief waarin samenwerking tussen de tweedelijnszorg en derdelijnszorg wordt geïntensiveerd. Het doel hiervan is het realiseren van goed functionerende ketenzorg voor patiënten met epilepsie.

In 2017 is er, op initiatief van de Nederlandse LIGA tegen Epilepsie, het Epilepsiefonds Nederland, en de Epilepsie Vereniging Nederland, gestart met het opzetten van het Nederlands Epilepsie Netwerk (NEN). In het netwerk wordt de samenwerking tussen tweede lijn (neurologen in algemene ziekenhuizen) en derde lijn (neurologen van de epilepsiecentra) geïntensiveerd, met als doel het bevorderen van de juiste zorg op de juiste plek en het verbeteren van de kwaliteit van zorg voor patiënten met epilepsie in het algemeen. Aanleiding is de observatie dat er in de epilepsiezorg weinig samenwerking bestaat tussen de tweede en derde lijn. De vraag die hieruit voortvloeit is of er wel sprake van goed functionerende ketenzorg voor patiënten met epilepsie is? Met andere woorden worden patiënten altijd op tijd verwezen naar de derde lijn en worden patiënten na beantwoording van de verwijsvraag ook weer tijdig naar de tweede lijn terugverwezen?

\section{Hoe werkt het Netwerk?}

Binnen het NEN gaan de epilepsiecentra partnerships aan met vakgroepen neurologie in algemene ziekenhuizen. Belangrijkste ingrediënt van een dergelijk partnership zijn gezamenlijke casuïstiek-besprekingen. Tijdens deze besprekingen kunnen de algemeen neurologen complexe casuïstiek inbrengen met vragen over diagnostiek of behandeling van mensen met epilepsie. Dergelijk overleg kan leiden tot een verwijzing naar het epilepsiecentrum, maar vaker kan de algemeen neuroloog zelf verder met de gegeven input voor het beleid. De neurologen van het epilepsiecentrum brengen patiënten in die verwezen zijn vanuit het betreffende algemeen ziekenhuis en koppelen terug wat de diagnostiek/en of behandeling binnen het epilepsiecentrum heeft opgeleverd. Door dit laagdrempelige, maar ook gestructureerde, overleg wordt bevorderd dat patiënten de juiste zorg op de juiste plek ontvangen. En wordt getracht de kwaliteit van zorg van deze patiënten op een hoger niveau te brengen.

Een extra invulling van de casuïstiekbesprekingen van neurologen die in de tweede en derde lijn werken kan zijn dat er een klinisch neurofysioloog van het epilepsiecentrum aanwezig is bij de bespreking. De klinisch neurofy- sioloog kan het EEG dat gemaakt werd bij het epilepsiecentrum bespreken en eventueel ook het EEG dat in het tweede lijn werd gemaakt beoordelen. De samenwerking tussen tweede en derde lijn kan ook aanleiding zijn om patiënten te verwijzen naar een verpleegkundig specialist van het epilepsiecentrum. Bijvoorbeeld voor voorlichting over epilepsie in het algemeen, maar ook meer specifiek over epilepsie en zwangerschap of over de mogelijkheden van aanvalsdetectie.

\section{Evaluatie van de werkwijze}

Er heeft in 2018-2019 een pilot plaatsgevonden waarin de werkwijze van de casuïstiekbesprekingen tussen neurologen van algemene ziekenhuizen en neurologen van epilepsiecentra werd geëvalueerd. Deze pilot is succesvol afgerond. Vanuit de algemene ziekenhuizen werd vooral een meerwaarde gezien in het laagdrempelig overleg en de korte lijnen.

Kempenhaeghe en SEIN hebben de ambitie dit netwerk uit te breiden. Hierbij wordt, onder anderen, gedacht aan samenwerkingsverbanden tussen de kinderneurologen van de epilepsiecentra en kinderartsen van algemene ziekenhuizen (dit initiatief is voor een deel ook al gerealiseerd). Er zijn gesprekken met de zorgverzekeraars over de vergoeding van de activiteiten in het kader van het NEN.

De poliklinieken van de epilepsiecentra zijn door het hele land gevestigd in of nabij algemene ziekenhuizen. Via deze (buiten)poliklinieken worden samenwerkingspartners benaderd. Uiteraard kan men bij interesse vanuit de algemene ziekenhuizen ook contact opnemen met de epilepsiecentra.

\section{Conclusie}

Een intensievere samenwerking tussen tweede en derde lijn zal bevorderen dat patiënten de juiste zorg op de juiste plek krijgen én de zorg voor epilepsiepatiënten in het algemeen bevorderen. 